DOI: 10.32089/WBH.phw.2019.2(268).0002

orcid.org/ 0000-0002-1115-6786

Piotr SAJA

\title{
Przygotowanie wojskowe młodzieży szkolnej i obozy letnie przysposobienia wojskowego ogólnego męskiego na Pomorzu pod koniec lat dwudziestych i w latach trzydziestych XX wieku
}

W okresie międzywojennym XX w. niepodległość Polski uzależniona była $\mathrm{w}$ dużym stopniu od własnych przedsięwzięć związanych z propagowaną wówczas ideą "narodu pod bronią". Przygotowanie młodego pokolenia do obrony kraju było ważnym elementem polityki władz cywilnych i wojskowych. W miarę możliwości organizacyjnych i finansowych starano się znaleźć jak najbardziej efektywne rozwiązanie tego problemu, mając na uwadze szybko zmieniającą się sytuację polityczną i militarną w Europie. Przez cały okres międzywojenny doskonalony był system przygotowania wojskowego młodzieży. Zadanie to realizowały głównie dwa resorty - Ministerstwo Spraw Wojskowych (MSWojsk.) i Ministerstwo Wyznań Religijnych i Oświecenia Publicznego (MWRiOP). Bardzo ważnym ogniwem w procesie szkolenia młodych ludzi były organizowane od 1922 r. obozy letnie przysposobienia wojskowego (PW). Ich koncepcję doskonalono przez lata, bazując na zebranych doświadczeniach.

Publikacja dotyczy przygotowania młodzieży męskiej szkolnej z przysposobienia wojskowego. Jest przyczynkiem i nie wyczerpuje ważnego - do tej pory - niewystarczająco opracowanego tematu, szczególnie w wymiarze regionalnym. Autor ukazuje w artykule, że prowadzone w okresie międzywojennym $\mathrm{XX}$ w. szkolenie miało nie tylko pozwolić na wyrobienie podstawowych umiejętności i nawyków ułatwiających późniejsze pełnienie służby w wojsku, lecz także wychować świadomego obywatela, obrońcę ojczyzny.

Ze względu na obowiązujące w periodykach wymogi wydawnicze autor zmuszony był ograniczyć się do selektywnego doboru treści merytorycznych 
związanych z tematem. Artykuł jest uzupełnieniem wydanej w 2009 r., na łamach „Przeglądu Historyczno-Wojskowego" publikacji dotyczącej obozów letnich PW dla młodzieży na Pomorzu w pierwszej połowie lat dwudziestych XX w. ${ }^{1}$

\section{Szkolenie z PW młodzieży}

W pierwszej połowie lat dwudziestych prace z zakresu PW na Pomorzu realizowane były przez podległe MSWojsk. Dowództwo Okręgu Korpusu (DOK) nr VIII w Toruniu, które w kwestiach dotyczących młodzieży szkolnej współpracowało z Kuratorium Okręgu Szkolnego Pomorskiego (KOSP). Te dwa organy władzy - wojskowy i cywilny - różniły się zasięgiem terytorialnym, podziałem administracyjnym i podległością w stosunku do władz zwierzchnich ${ }^{2}$. Wymagało to koordynacji działań i konsultacji. Nie zawsze współpraca układała się poprawnie. Troska władz kuratoryjnych, aby stworzyć jak najlepsze zaplecze dla szkolenia młodzieży i - tym samym - zapewnić jej odpowiednie warunki bytowe w czasie obozów letnich PW, bywała czasami powodem nieporozumień z władzami wojskowymi odpowiedzialnymi za ich organizację. Nie wynikało to ze złej woli, lecz przede wszystkim z ograniczonych możliwości finansowych i materiałowych wojska oraz braku doświadczenia w tej dziedzinie. Z czasem udało się jednak wypracować odpowiedni sposób szkolenia z PW i organizacji obozów letnich.

$\mathrm{Na}$ najniższym szczeblu sprawami administracyjnymi związanymi z przygotowaniem do obozów letnich PW zajmowali się oficerowie instrukcyjni urzędujący w powiatowych komendach uzupełnień (PKU) ${ }^{3}$. W porozumieniu z dyrekcjami szkół sporządzali oni zbiorcze listy z deklaracjami uczestnictwa, które przesyłane były do referenta Przysposobienia Rezerw Oddziału III (a od 1924 r. Referatu Przysposobienia Wojskowego Oddziału Wyszkolenia) DOK. Na szczeblu wyższym leżało to w gestii DOK nr VIII i KOSP. W 1925 r. Ministerstwo Spraw Wojskowych dokonało reorganizacji

\footnotetext{
P. Saja, „Naród pod bronia”. Obozy letnie przysposobienia wojskowego dla młodzieży szkolnej i pozaszkolnej na Pomorzu w latach 1922-1925, „Przegląd Historyczno-Wojskowy” (dalej: PHW) 2009, nr 4 (229), s. 25-40.

2 Jeśli wziąć pod uwagę administracyjno-wojskowy podział kraju, to obszar DOK nr VIII obejmował, uwzględniając podział administracyjno-cywilny: województwo pomorskie, część powiatów należących do województwa poznańskiego (inowrocławski, mogileński, żniński, wągrowiecki, wyrzyski, chodzieski, bydgoski, szubiński), a także warszawskiego (rypiński, lipnowski, włocławski, nieszawski). Ta rozbieżność w podziale administracyjnym powodowała, że DOK nr VIII, realizując szkolenie z zakresu PW dla młodzieży szkolnej, oprócz współpracy z KOSP współdziałało także z Kuratorium Okręgu Szkolnego Poznańskiego i Kuratorium Okręgu Szkolnego Warszawskiego.

3 P. Saja, „Naród pod bronia”. Obozy letnie przysposobienia wojskowego dla młodzieży szkolnej i pozaszkolnej..., s. 30.
} 
w strukturach władz terenowych PW. Zlikwidowane zostały funkcje oficerów instrukcyjnych w PKU. Ich zadania przejęli oficerowie PW pełniący tę funkcję przy pułkach piechoty i rejonach dywizyjnych.

Po zamachu stanu Józefa Piłsudskiego z maja 1926 r. wzrosło znaczenie MSWojsk. jako ważnego organu kierującego i koordynującego prace związane z przygotowaniami społeczeństwa na wypadek wojny. Rozporządzeniem Rady Ministrów z 28 stycznia 1927 r. utworzony został Państwowy Urząd Wychowania Fizycznego i Przysposobienia Wojskowego (PUWFiPW) podporządkowany MSWojsk. ${ }^{4}$ Rozporządzenie powoływało również Radę Naukową oraz wojewódzkie, powiatowe i miejskie komitety wychowania fizycznego i przysposobienia wojskowego (WFiPW) ${ }^{5}$. Zastąpiły one komitety WFiPW, które istniały od 1925 r. i podlegały Radzie Naczelnej WFiPW podporządkowanej MWRiOP. PUWFiPW utworzony został w celu kierowania pracami związanymi z rozwojem wychowania fizycznego i szkolenia wojskowego poza armią, lecz we współdziałaniu ze strukturami podległymi MSWojsk. ${ }^{6} 13$ grudnia 1927 r. PUWFiPW wydał instrukcję o wyszkoleniu oddziałów PW. Zgodnie z jej treścią przygotowanie z PW obejmowało kilka kategorii osób. Zaliczano do nich młodzież szkolną, młodzież pozaszkolną, młodzież akademicką, rezerwistów oraz kobiety

Wprowadzone zostały również zmiany w strukturze organizacyjno-terytorialnej. PUWFiPW podlegały, utworzone na przełomie 1928/29 r. na szczeblu DOK, Okręgowe Urzędy WFiPW (OUWFiPW). Były to organy robocze dowódcy okręgu korpusu $(\mathrm{OK})$ w sprawach związanych z przysposobieniem wojskowym i wychowaniem fizycznym. Ponadto przy dowództwach dywizji powstały rejonowe komendy WFiPW, będące organami wykonawczymi dowódców dywizji w dziedzinie $\mathrm{PW}^{8}$. Każda obejmowała obszar należący do jednej

4 Rozporządzenie Rady Ministrów z 28 I 1927 r. w sprawie utworzenia Państwowego Urzędu Wychowania Fizycznego i Przysposobienia Wojskowego oraz wojewódzkich, powiatowych i miejskich komitetów wychowania fizycznego i przysposobienia wojskowego (M.P. 1927, nr 26, poz. 59, s. 40); J. Kęsik, Naród pod bronią. Społeczeństwo w programie polskiej polityki wojskowej, 1918-1939, Wrocław 1998, s. 74-75; szerzej P. Rozwadowski, Państwowy Urząd Wychowania Fizycznego i Przysposobienia Wojskowego, Warszawa 2000, s. 25 i n.

5 Szerzej P. Saja, Komitety Wychowania Fizycznego i Przysposobienia Wojskowego w województwie pomorskim w okresie Drugiej Rzeczypospolitej, Toruń 2012, s. 83-85; P. Rozwadowski, Państwowy Urząd Wychowania..., s. 76-80; Rada Naukowa Wychowania Fizycznego, „Wychowanie Fizyczne” 1927, z. 4, s. 100-101; 1927, z. 6 (dokończenie), s. 156-158.

$6 \quad$ P. Saja, Komitety Wychowania Fizycznego..., s. 82; L. Wyszczelski, Ministerstwo Spraw Wojskowych (1918-1939), Warszawa 2010, s. 156-157; J. Wojtycza, Przysposobienie wojskowe w odrodzonej Polsce do 1926 roku, Kraków 2001, s. 143-149; J. Kęsik, Naród pod broniq..., s. 74-75.

L. Wyszczelski, Ministerstwo Spraw..., s. 156.

8 Archiwum Państwowe w Bydgoszczy (dalej: AP w Bydgoszczy), Urząd Wojewódzki Pomorski (UWP) w Toruniu 1920-1939, sygn. 9204, Wojewódzki Komitet WF i PW w Toruniu 
Z trzech dywizji piechoty, jakie stacjonowały na terenie każdego DOK. Z kolei przy dowództwach pułków piechoty utworzone zostały obwodowe komendy PW podległe dowódcom pułków. W skład obwodu pułkowego wchodziły 2-3 powiaty. Komendom obwodowym podlegały powiatowe komendy PW. Organy te pod koniec lat dwudziestych i w latach trzydziestych były bezpośrednio odpowiedzialne za organizację i rozwój PW w terenie. Do obowiązków komend powiatowych PW należało m.in.:

- wyszkolenie i zaopatrzenie jednostek PW na podległym obszarze,

- prowadzenie wychowania fizycznego w powiecie, w szczególności w oddziałach PW,

- współpraca z władzami administracyjnymi, szkolnymi, instytucjami samorządowymi i społecznymi, a także zarządami działających w powiecie stowarzyszeń, w których prowadzone było przysposobienie wojskowe?

W skład każdej powiatowej komendy PW wchodzili: powiatowy komendant PW, personel pomocniczy i kadra instruktorska. Komendantowi powiatowemu PW podlegały wszystkie jednostki PW istniejące na obszarze powiatu ${ }^{10}$. Do jednostek PW zaliczane były hufce szkolne i pozaszkolne młodzieży oraz oddziały i drużyny PW istniejące $\mathrm{w}$ ramach działających $\mathrm{w}$ powiecie organizacji i stowarzyszeń paramilitarnych, kombatanckich i społecznych.

Na obszarze DOK nr VIII, z siedzibą w Toruniu, ogólne kierownictwo nad działalnością związaną z PW sprawował dowódca OK. Jego organem roboczym był 8 Okręgowy Urząd WFiPW. Okręg WFiPW dzielił się na rejony WFiPW. Każdy rejon zasadniczo pokrywał się z obszarem pokojowego rozmieszczenia jednej dywizji piechoty. Ponieważ na obszarze DOK nr VIII stacjonowały trzy dywizje piechoty, 8 Okręg WFiPW liczył 3 rejony. Były to rejony: 4 Dywizji Piechoty (DP) - z miejscem postoju dowództwa w Toruniu, 15 DP - z miejscem postoju dowództwa w Bydgoszczy i 16 DP - z miejscem postoju dowództwa w Grudziądzu ${ }^{11}$.

Przysposobienie wojskowe wprowadzone zostało już na początku lat dwudziestych, lecz w ograniczonym zakresie. W okresie międzywojennym przeszło ono ewolucję. Władze wojskowe i cywilne stopniowo upowszechniały je nie tylko w placówkach oświatowych, lecz także w organizacjach i stowarzyszeniach paramilitarnych i społecznych. W wyniku porozumienia

- instrukcje 1927-1931, t. 1: „Władze i jednostki wychowania fizycznego i przysposobienia wojskowego. Przepisy służbowe MSWojsk.", Warszawa 1928, s. 15-17.

9 Ibidem, s. 19.

10 Ibidem, s. 20.

11 Archiwum Państwowe w Toruniu (dalej: AP w Toruniu), Akta miasta Torunia (dalej: AmT), sygn. 5573, Instrukcje dla organizacji pracy PW i formacji paramilitarnych 19291939, „Podział terytorialny organizacji pracy PW. Instrukcja nr 5”, Warszawa 1929, s. 8. 
MSWojsk. z MWRiOP 1 grudnia 1922 r. wydane zostało rozporządzenie obu ministrów dotyczące organizacji przysposobienia wojskowego w szkołach średnich i zawodowych ${ }^{12}$. Jego uzupełnieniem był wydany przez MSWojsk., 1 stycznia 1923 r. rozkaz zawierający zarządzenie wykonawcze dotyczące tworzenia hufców $\mathrm{PW}^{13}$. To samo zarządzenie ukazało się również $\mathrm{w}$ rozporządzeniu opublikowanym 5 stycznia 1923 r. przez MWRiOP ${ }^{14}$. Zgodnie $\mathrm{z}$ treścią zarządzeń o wyborze szkól, w których mogło być prowadzone nauczanie z przysposobienia wojskowego, decydowały kuratoria okręgów szkolnych w porozumieniu z właściwymi DOK. Szkolenie mogło być organizowane w szkołach zawodowych, średnich, wyższych i seminariach nauczycielskich, o ile zgłosi się odpowiednia liczba chętnych. Przynależność do hufców była dobrowolna. Nauka PW dotyczyła młodzieży męskiej, która ukończyła 16 lat i cieszyła się dobrym stanem zdrowia. Począwszy od 1923 r., hufce szkolne PW zaczęły być tworzone na szerszą skalę. Tendencja ta widoczna była również w województwie pomorskim, gdzie władze KOSP sugerowały dyrekcjom szkół potrzebę tworzenia nowych hufców PW. I tak np. kurator Jan Szwemin w styczniu 1926 r. wydał okólnik, w którym czytamy: „Z uwagi na projekt ustawy o powszechnym obowiązku wychowania fizycznego młodzieży i o przysposobieniu wojskowym, zatwierdzony przez Radę Ministrów i przekazany ciałom ustawodawczym, niewątpliwie będzie uchwalony, uważam już teraz za wskazane zwrócić uwagę na to, że stanie się wówczas przedmiotem obowiązkowym w szkołach [...] Nie zamierzając przed uchwaleniem wspomnianej na początku ustawy nakładać na szkoły obowiązku tworzenia hufców szkolnych polecam Dyrekcjom i Kierownictwom tych szkół, w których organizacji tego rodzaju nie ma dotychczas, aby wspólnie z Radami Pedagogicznymi ponownie rozważyły, czy nie nastąpiły już obecnie warunki sprzyjające założeniu hufca szkolnego"15.

$\mathrm{Na}$ początku lat trzydziestych nastąpiła zmiana. Na mocy zarządzenia MSWojsk. i MWRiOP z 4 lutego 1931 r. udział młodzieży w zajęciach hufców szkolnych, w placówkach oświatowych, szkołach średnich ogólnokształcących, seminariach nauczycielskich i szkołach zawodowych stał się obowiązkowy, a nie jak wcześniej dobrowolny, o ile zgodę na to wyrażą

12 Rozporządzenie Ministra Wyznań Religijnych i Oświecenia Publicznego i Ministra Spraw Wojskowych z 1 XII 1922 r. w sprawie organizacji przysposobienia wojskowego w szkołach średnich i zawodowych (Dz. U. M. W. R. i O. P. 1923, nr 1, poz. 2, s. 2-5).

13 J. Wojtycza, Przysposobienie wojskowe..., s. 58.

14 Rozporządzenie Ministra Wyznań Religijnych i Oświecenia Publicznego z 5 I 1923 r. w sprawie przysposobienia wojskowego młodzieży szkolnej (Dz. U. M. W. R. i O. P. 1923, nr 1, poz. 3, s. 5-7).

15 AP w Bydgoszczy, Kuratorium Okręgu Szkolnego Pomorskiego (dalej: KOSP) w Toruniu, sygn. 3582, KOSP w Toruniu - okólniki 1926 r., Okólnik KOSP w sprawie hufców szkolnych PW, 8 I 1926 r., k. 5. 
władze właściwego kuratorium działające $\mathrm{w}$ porozumieniu $\mathrm{z}$ miejscowym DOK $^{16}$. Obowiązek obejmował młodzież męską szkół państwowych i niepaństwowych. Ponadto w programach szkolnych, w ramach przedmiotów nauczania takich jak np. geografia, historia, wychowanie fizyczne, język polski, fizyka, pojawiły się treści przydatne w szeroko rozumianym przygotowaniu wojskowym. Narastające zagrożenie ze strony Niemiec i ZSRR spowodowało kolejne zmiany mające na celu lepsze przygotowanie młodego pokolenia do obrony kraju. 10 września 1937 r. MSWojsk. i MWRiOP wydały wspólne zarządzenie wprowadzające w szkołach obowiązek nauki przysposobienia wojskowego dla młodzieży męskiej i przysposobienia do służby pomocniczej młodzieży żeńskiej ${ }^{17}$.

Jak wspomniano na wstępie artykułu, szkolenie z przysposobienia wojskowego miało na celu przygotowanie młodzieży jako przyszłych obrońców kraju. Ważne było przy tym także wychowanie obywatela-patrioty. I tak np. w zarządzeniu wydanym 4 lutego 1931 r. przez PUWFiPW MSWojsk. czytamy:

„1. Celem przysposobienia wojskowego w szkołach jest:

a) wyrabianie w młodzieży czynnego patriotyzmu, w szczególności zaś poczucia państwowego wyrażającego się w gotowości poniesienia wszelkich ofiar w obronie państwa,

b) rozwijanie hartu woli, obowiązkowości i karności,

c) pomnażanie sił fizycznych młodzieży przez nauczanie sprawności wojskowych i odbywanie ćwiczeń polowych,

d) budzenie zaufania do służby wojskowej i przygotowanie do niej”"18.

Podobne cele co do kształtowania postaw pronarodowych i propatriotycznych, a dotyczące nauki PW $\mathrm{w}$ szkołach, zawarte zostały $\mathrm{w}$ rozporządzeniu MWRiOP i MSWojsk. z 10 września 1937 r. W tym dokumencie cele i zadania przysposobienia młodzieży szkolnej do obrony kraju przedstawiono następująco:

\footnotetext{
16 AP w Bydgoszczy, KOSP w Toruniu, sygn. 52, Wychowanie fizyczne i przysposobienie wojskowe - 1931 r., Zarządzenie Ministra Wyznań Religijnych i Oświecenia Publicznego i Ministra Spraw Wojskowych z 4 II 1931 r. w sprawie przysposobienia wojskowego w szkołach średnich ogólnokształcących, seminariach nauczycielskich i szkołach zawodowych, k. 197; J. Kęsik, Naród pod bronią..., s. 83.

17 AP w Bydgoszczy, KOSP w Toruniu, sygn. 54, Wychowanie fizyczne i przysposobienie wojskowe 1937-1938, Zarządzenie Ministra Wyznań Religijnych i Oświecenia Publicznego oraz Ministra Spraw Wojskowych z 10 IX 1937 r. w sprawie organizacji przysposobienia młodzieży szkolnej do obrony kraju, zał. nr 1, pkt. II,§ 3, k. 302; J. Kęsik, Naród pod bronią..., s. 83.

18 AP w Bydgoszczy, KOSP w Toruniu, sygn. 52, Wychowanie fizyczne i przysposobienie wojskowe - 1931 r., Zarządzenie Ministra Wyznań Religijnych i Oświecenia Publicznego i Ministra Spraw Wojskowych z 4 II 1931 r. w sprawie przysposobienia wojskowego w szkołach średnich ogólnokształcących, seminariach nauczycielskich i szkołach zawodowych, k. 197.
} 
„1. Celem przysposobienia młodzieży szkolnej do obrony kraju jest przygotowanie uświadomionych, czynnych, dzielnych i karnych obywateli gotowych w każdej chwili stanąć w jego obronie przed grożącym z jakiejkolwiek strony niebezpieczeństwem. Przysposobienie młodzieży szkolnej do obrony kraju jest podstawowym zadaniem pracy wychowawczej i dydaktycznej każdej szkoły.

2. Przysposobienie młodzieży do obrony kraju obejmuje:

a) ogólne przygotowanie do obrony kraju,

b) przysposobienie wojskowe (młodzieży żeńskiej do służby pomocniczej kobiet).

Ogólne przygotowanie młodzieży do obrony kraju realizuje się przez całą pracę wychowawczą i dydaktyczną każdej szkoły.

Przysposobienie wojskowe młodzieży realizuje się w szkołach średnich ogólnokształcących i zawodowych oraz w szkołach dokształcających zawodowych, w których uczniowie odpowiadają przeciętnie wiekowi od 15 lat wzwyż, według obowiązujących programów szkolnych"19.

Ogólne kierownictwo, opiekę i kontrolę nad działalnością hufca szkolnego sprawował dyrektor szkoły i rada pedagogiczna. Hufce szkolne męskie, a od 1937 r. także żeńskie, były jednostkami PW. Nosiły nazwę oraz imię i nazwisko patrona szkoły, w której istniały. Nadzór nad szkoleniem wojskowym hufców męskich pełnił obwodowy komendant PW we współpracy z komendantami powiatowymi PW. Z kolei fachową opiekę nad żeńskimi

19 AP w Bydgoszczy, KOSP w Toruniu, sygn. 54, Wychowanie fizyczne i przysposobienie wojskowe 1937-1938, Zarządzenie Ministra Wyznań Religijnych i Oświecenia Publicznego oraz Ministra Spraw Wojskowych z 10 IX 1937 r. w sprawie organizacji przysposobienia młodzieży szkolnej do obrony kraju, pkt. I, $₫ 1$, k. 301.

Uzupełnieniem wyżej podanego zarządzenia było zamieszczone, w wydawanym od początku 1938 r. przez PUWFiPW „Dzienniku Zarządzeń”, dodatkowe zarządzenie. Zgodnie z jego treścią do czasu opublikowania przez PUWFiPW „Wytycznych wyszkolenia dla hufców szkolnych" w szkołach realizowany będzie program, w myśl którego:

„1. Celem przysposobienia młodzieży do obrony kraju jest przygotowanie w szkole i przez szkołę zastępów uświadomionych obywateli kraju, gotowych do wypełnienia obowiązku.

2. Przysposobienie młodzieży szkolnej do obrony kraju wchodzi obecnie w całokształt prac i zadań szkoły jako obowiązujące.

Dzieli się ono na:

a) ogólne przygotowania do obrony kraju:

Ogólna obrona plot. i pgaz. odbywa się w ramach ogólnych przedmiotów rozpoczynając się w szkole powszechnej, trwa przez cały czas nauki we wszystkich szkołach, w zakresie dostosowanym do wieku młodzieży i typu szkoły. Przygotowanie to prowadzi całe grono wychowawców i nauczycieli, szkoła w całokształcie pracy i wychowania.

b) właściwe przysposobienie wojskowe:

Prowadzą w hufcach szkolnych, w ramach planu lekcyjnego, specjalnie do tej pracy przygotowani nauczyciele, komendanci hufców PW". Zob. AP w Toruniu, AmT, sygn. 5935, Organizacje WFiPW, Hufce szkolne PW - reorganizacja, „Dziennik Zarządzeń” 1938, nr 2, poz. 11. 
hufcami szkolnymi sprawowała instruktorka przysposobienia wojskowego kobiet, wyznaczona przez dowódcę danego $\mathrm{OK}^{20}$. Uczniów należących do hufca szkolnego nazywano junakami ${ }^{21}$. Podlegali oni przepisom szkolnym. W czasie zajęć hufca PW obowiązywała dyscyplina wzorowana na wojskowej. Junaków ubranych w mundur obligowały przepisy o zachowaniu podobne do tych, jakie przestrzegać musieli uczniowie szkół kadeckich. Junaczki natomiast nosiły mundurki szkolne. Męski hufiec dzielił się na plutony i drużyny, a żeński na drużyny, sekcje i patrole ${ }^{22}$.

Komendantami męskich hufców szkolnych byli przeważnie oficerowie. Funkcję tę mogli pełnić oficerowie zawodowi, oficerowie rezerwy lub kontraktowi, a w drugiej połowie lat trzydziestych także podchorążowie posiadający wymaganą wiedzę i praktykę wojskową, wyznaczeni przez komendanta właściwego obwodu PW i zatwierdzeni przez kuratorium okręgu szkolnego i DOK, na wniosek dyrektora szkoły ${ }^{23}$. Do pomocy komendantom hufców szkolnych PW pomocników instruktorów kontraktowych przydzielał powiatowy komendant PW spośród osób zatwierdzonych na swojej funkcji przez OUWFiPW. Zgodnie z zarządzeniem MWRiOP wydanym w porozumieniu MSWojsk. - 4 lutego 1931 r. każdy hufiec posiadał także kierownika pedagogicznego. Był nim nauczyciel (najczęściej wychowania

20 AP w Bydgoszczy, KOSP w Toruniu, sygn. 54, Wychowanie fizyczne i przysposobienie wojskowe 1937-1938, Zarządzenie Ministra Wyznań Religijnych i Oświecenia Publicznego oraz Ministra Spraw Wojskowych z 10 IX 1937 r. w sprawie organizacji przysposobienia młodzieży szkolnej do obrony kraju, zał. nr 1, pkt. II, $\$ 5$, k. 302.

${ }^{21}$ W maju 1932 r. PUWFiPW MSWojsk. wydał zarządzenie ujednolicające stosowanie nazw używanych w PW. Zgodnie z jego treścią należy stosować podane niżej terminy i określenia, które mają następujące znaczenie:

„junak” - oznacza członka PW należącego do hufca PW,

„junak młody” - oznacza członka PW I stopnia,

„junak starszy” - oznacza członka PW II stopnia,

„strzelec” - oznacza absolwenta II stopnia PW,

„szkoła młodszych" - oznacza I stopień PW,

„szkoła starszych” - oznacza II stopień PW.

Zob. AP w Bydgoszczy, KOSP w Toruniu, sygn. 53, Wychowanie fizyczne i przysposobienie wojskowe 1931-1932, Odpis zarządzenia Dyrektora PUWFiPW MSWojsk. ppłk. dypl. Władysława Kilińskiego z 31 V 1932 r. dotyczącego nazw i oznaczeń używanych w PW, s. 1.

22 AP w Bydgoszczy, KOSP w Toruniu, sygn. 48, Wychowanie fizyczne i przysposobienie wojskowe 1932-1939, Tymczasowy regulamin hufców szkolnych. Zał. do rozporządzenia nr II W-1768/38, \$ 11, [1938 r.], k. 57.

23 AP w Bydgoszczy, KOSP w Toruniu, sygn. 54, Wychowanie fizyczne i przysposobienie wojskowe 1937-1938, Instrukcja wyszkolenia w przysposobieniu wojskowym, cz. II: „Szkolenie przedpoborowych w PW ogólnym, Hufce szkolne gimnazjum i liceów ogólnokształcących”, Warszawa 1938, rozdział I: „Organizacja szkolenia”, pkt. 4-6, k. 239-241; Zarządzenie Ministra Wyznań Religijnych i Oświecenia Publicznego oraz Ministra Spraw Wojskowych z 10 IX 1937 r. w sprawie organizacji przysposobienia młodzieży szkolnej do obrony kraju, zał. nr 1, pkt. II, $\$ 7$, k. 302. 
fizycznego) danej placówki oświatowej, wybrany przez dyrekcję szkoły spośród grona pedagogicznego i zatwierdzony przez kuratorium i DOK. Do jego obowiązków należały sprawy związane z organizacją hufca, nadzór nad czynnościami administracyjnymi, czuwanie nad porządkiem i dyscypliną wśród uczniów, kontrola realizacji programu przysposobienia wojskowe$\mathrm{go}^{24}$. Pod koniec lat trzydziestych kierownik pedagogiczny pełnił funkcję zastępcy komendanta hufca szkolnego PW.

Program szkolenia z PW był dwustopniowy. Ustalały go MWRiOP w porozumieniu z PUWFiPW MSWojsk. Obejmował on zarówno junaków hufców szkolnych, jak i przedpoborowych i poborowych należących do drużyn i oddziałów młodzieżowych istniejących w organizacjach paramilitarnych i społecznych np. Związku Strzeleckim, drużynach Towarzystw Powstańców i Wojaków, Towarzystwie Gimnastycznym „Sokół”. Pod koniec lat dwudziestych XX w. przedstawiał się on następująco:

a) I stopień PW

Program szkolenia dla I stopnia realizowany był w ciągu jednego roku. Obejmował swym zakresem dwumiesięczny cykl wyszkolenia rekruckiego piechoty - dla poborowych bez cenzusu (do takich zaliczano uczniów szkół wydziałowych i niższych np. zawodowych, rolniczych, handlowych, przemysłowych itp.) i trzymiesięczne szkolenie podstawowe przed szkołą podchorążych - dla poborowych z cenzusem (za takich uważano uczniów, którzy ukończyli szkoły ogólnokształcące, średnie techniczne, seminaria nauczycielskie i szkoły zawodowe na prawach szkół średnich).

b) II stopień PW

Swym zakresem obejmował szkolenie w ramach drużyny piechoty. Dla poborowych bez cenzusu rozłożony był na okres dwóch lat. Natomiast dla poborowych z cenzusem obejmował całość szkolenia podstawowego i miał być realizowany w ciągu dwóch lat lub w ciągu jednego roku i obozu letniego ${ }^{25}$.

Treści merytoryczne I i II stopnia PW były modyfikowane w zależności od potrzeb szkoleniowych. Sposób i warunki otrzymania stopnia PW określały instrukcje wydawane przez PUWFiPW MSWojsk. ${ }^{26}$

\footnotetext{
24 AP w Bydgoszczy, KOSP w Toruniu, sygn. 52, Wychowanie fizyczne i przysposobienie wojskowe - 1931 r., Zarządzenie Ministra Wyznań Religijnych i Oświecenia Publicznego i Ministra Spraw Wojskowych z 4 II 1931 r. w sprawie przysposobienia wojskowego w szkołach średnich ogólnokształcących, seminariach nauczycielskich i szkołach zawodowych, k. 197.

25 M. Fularski, Przysposobienie wojskowe w Polsce, Warszawa 1929, s. 237-241 (aneksy: Rozporządzenie o stosowaniu ulg w służbie czynnej dla członków przysposobienia wojskowego - MSWojsk. PUWFiPW).

26 I tak np. instrukcja PUWFiPW MSWojsk. wydana w 1932 r. zakładała następujące warunki otrzymania stopni.

„a) I stopień PW otrzymują członkowie jednostek PW, którzy:
} 
W szkołach na wyszkolenie wojskowe, bez wychowania fizycznego, przeznaczano według obowiązującego programu sto godz. rocznie, po dwie godz. tygodniowo w ramach zajęć szkolnych. Raz w miesiącu organizowane były ćwiczenia w czasie wolnym od zajęć lekcyjnych. Na zakończenie szkolenia II stopnia organizowano w lipcu i sierpniu obozy letnie, mające za zadanie uzupełnić i utrwalić zdobytą przez uczniów wiedzę i umiejętności praktyczne ${ }^{27}$. Całość zakończona była egzaminem.

Zdobycie stopni PW dawało pewne przywileje i ulgi. Poborowi mieli możliwość wyboru rodzaju broni $\mathrm{w}$ ramach zapotrzebowania, jakie otrzymała działająca na ich terenie Powiatowa Komenda Uzupełnień. Poborowi bez cenzusu po zaliczeniu I stopnia PW - przy zachowaniu nienagannej dyscypliny - mieli pierwszeństwo w wyborze szkół podoficerskich, awansie na starszego szeregowego, w przyznaniu urlopów na święta lub otrzymaniu przepustek zezwalających w okresie rekruckim na wyjście poza koszary. Po ukończeniu II stopnia PW poborowi bez cenzusu mieli takie same przywileje jak za I stopień, a ponadto służąc w piechocie, kawalerii i lotnictwie, mieli prawo do skrócenia służby czynnej o trzy miesiące, przez późniejsze

- według oceny powiatowego komendanta PW opanowali w co najmniej dostatecznym stopniu program ustalony programami i wytycznymi PUWFiPW MSWojsk., przewidzianymi na dany okres szkoleniowy,

- mają zapisane w książeczkach PWiWF i w dziennikach kontroli zajęć odbycie przynajmniej 85\% ćwiczeń, zbiórek i marszów, a także zaliczone strzelania szkolne z kbk i kbks,

- wykazują się umiejętnością czytania i pisania w języku polskim oraz mają ogólne wiadomości o Polsce.

b) II stopień uzyskują członkowie PW, którzy:

- opanowali programy I i II stopnia PW, ukończyli obóz letni PW lub kurs (organizowany przez komendy obwodowe PW przy dywizjach piechoty), ewentualnie odbyli koncentrację,

- zdali egzamin przed powołaną w tym celu komisją i otrzymali z niego przynajmniej ocenę dostateczną,

- w książeczkach PWiWF i danych ewidencyjnych zawartych w dzienniku kontroli zajęć odbyli ćwiczenia i strzelania przewidziane w programach i wytycznych dla II stopnia PW, w tym $85 \%$ zbiórek i marszów,

- 2 lata brali udział w ćwiczeniach hufów i oddziałów PW,

- mają elementarną wiedzę z wychowania obywatelskiego,

- mają Państwową Odznakę Sportową lub brali udział w próbach jej otrzymania."

Ukończenie szkolenia z zakresu II stopnia PW wpisywane było przez komendanta obozu PW (kursu), ewentualnie komendanta powiatowego PW do książeczek PWiWF i przesyłane było do komendanta odpowiedniego obwodu PW, który na tej podstawie wydawał świadectwo II stopnia PW. Szerzej zob. AP w Bydgoszczy, KOSP w Toruniu, sygn. 53, Wychowanie fizyczne i przysposobienie wojskowe 1930-1932, Instrukcja nr 17 PUWFiPW MSWojsk. o przeprowadzaniu egzaminów i wydawaniu zaświadczeń pracy w PW, cz. I, \$1-2, Warszawa 1932.

27 P. Saja, Organizacja władz przysposobienia wojskowego na obszarze DOK nr VIII na przełomie lat dwudziestych i trzydziestych XX wieku [w:] Materiały z III międzynarodowej konferencji naukowej p.h. Od armii komputowej do narodowej. Problemy organizacyjne sił zbrojnych od XVI do XX wieku, red. J. Centek i M. Krotofil, Toruń 2009, s. 310. 
wcielenie do wojska ${ }^{28}$. Natomiast odbywający służbę wojskową w artylerii mogli mieć ją skróconą również o trzy miesiące, tyle że przez wcześniejsze zwolnienie do rezerwy. $Z$ kolei poborowi z cenzusem otrzymywali podobne przywileje jak poborowi bez cenzusu, a oprócz tego mogli ubiegać się o tytuł podchorążego rezerwy ${ }^{29}$.

W latach trzydziestych XX w. szkolenie z przysposobienia wojskowego $\mathrm{w}$ szkole ewoluowało. Zmieniano treści programowe w nauczaniu, nadając im szerszy zakres merytoryczny i praktyczny. Instytucją odpowiedzialną za zmiany był nadal PUWFiPW podległy MSWojsk.

W 1938 r. zajęcia prowadzone w hufcach PW obejmowały:

a) Hufce żeńskie:

- 2 godziny zajęć w ramach tygodniowego planu szkolnego,

- 4 ćwiczenia półdniowe,

- kilkudniowy obóz żeński.

b) Hufce męskie:

- 2 godziny lekcji w ramach tygodniowego planu nauki szkolnej,

- 4 ćwiczenia półdniowe i 5 ćwiczeń nocnych,

- kilkudniowe ćwiczenia organizowane w miarę możliwości w każdej klasie pod koniec roku szkolnego,

- obóz letni PW w czasie wakacji ${ }^{30}$.

Wspomniane wyżej kilkudniowe ćwiczenia hufca męskiego PW miały na celu wdrożyć junaków do życia w warunkach obozu polowego, umożliwić zrealizowanie ćwiczeń praktycznych, których nie można było przeprowadzić wcześniej, w czasie trwania roku szkolnego (np. strzelań), ze względu na zaplanowany rozkład zajęć. Było to bardzo przydatne i pozwalało przygotować młodzież do obozów PW odbywających się w czasie wakacji. W obozie PW mogli uczestniczyć tylko ci junacy, którzy otrzymali promocję do następnej klasy i przeszli pomyślnie okresowe badania lekarskie.

\section{Obozy letnie PW ogólnego dla młodzieży szkolnej - uwagi ogólne}

Głównym celem obozów było dokończenie szkolenia młodzieży w zakresie II stopnia PW, przede wszystkim przez praktyczne przerobienie określonej części programu ustalonego na dany rok szkolny PW, w postaci wytycznych i instrukcji wydawanych przez PUWFiPW MSWojsk. Aby

\footnotetext{
28 M. Fularski, Przysposobienie wojskowe..., s. 240 (aneksy: Rozporządzenie o stosowaniu ulg w stużbie czynnej).

29 P. Saja, Organizacja władz przysposobienia wojskowego..., s. 311.

30 AP w Bydgoszczy, KOSP w Toruniu, sygn. 48, Wychowanie fizyczne i przysposobienie wojskowe 1932-1939, Tymczasowy regulamin hufców szkolnych. Zał. do rozporządzenia nr II W-1768/38, § 13-14, [1938 r.], k. 57-58.
} 
to osiągnąć, junacy musieli uczestniczyć w ćwiczeniach przeprowadzanych w odpowiednich warunkach technicznych i terenowych, zbliżonych do warunków polowych. Ponadto celem obozów było także budzenie wśród młodzieży zamiłowania do kultury fizycznej, otaczającej przyrody oraz wyrobienie nawyków ułatwiających życie w grupie.

Obozy letnie PW ogólnego młodzieży męskiej szkolnej od strony organizacyjnej przeszły wiele zmian związanych z czasem trwania, liczbami obozów i młodzieży biorącej w nich udział. W latach 1922-1927, na szczeblu centralnym, kwestią dotyczącą obozów PW zajmował się Oddział III Sztabu Generalnego, a potem PUWFiPW podporządkowany MSWojsk. Planowane były zawsze w okresie wakacyjnym, od końca czerwca do końca sierpnia, kiedy młodzież nie chodziła do szkoły. W pierwszej połowie lat dwudziestych liczba organizowanych przez DOK nr VIII obozów PW ogólnego dla młodzieży szkolnej wahała się w granicach od 5 do 9, a liczba zaplanowanych miejsc dla uczestników wynosiła od 430 do $900^{31}$. Jednak nie zawsze limity w pełni były wykorzystane. W późniejszym okresie liczba organizowanych obozów zmieniała się, wykazując pewne wahania, podobnie jak liczba uczestników. Bliższe dane z wybranych lat zawiera tabela 1.

Na stosunkowo powolny wzrost liczby uczestników i przygotowywanych obozów złożyło się kilka przyczyn. Jedną z ważniejszych były problemy finansowe spowodowane panującym $\mathrm{w}$ kraju w pierwszej połowie lat trzydziestych wielkim kryzysem ekonomicznym. Wojsko nie dysponowało odpowiednio dużymi funduszami na szkolenie PW i organizację obozów. Dlatego też starano się zdobyć dodatkowe środki od samorządów oraz miejskich i powiatowych komitetów WFiPW. Ponadto istniały trudności w doborze kadry wojskowej odpowiednio przygotowanej do pracy z młodzieżą. Warto też wspomnieć, że obozy letnie PW ogólnego nie były jedynymi, jakie organizował OUWFiPW DOK nr VIII. W okresie wakacyjnym przygotowywał on także obozy letnie PW dla młodzieży pozaszkolnej, młodzieży wieczorowych szkół dokształcających zawodowych, obozy dla instruktorów PW, obozy PW specjalnego, obozy dla instruktorów WF, obozy dla członków ZHP.

Na miejsce obozów władze DOK nr VIII wybierały głównie tereny w pobliżu miejscowości leżących nad morzem np. w okolicy Poczernina w 1928 r., a w latach trzydziestych w Cetniewie i w pobliżu Lidzbarka Pomorskiego. Tam też odpowiednio przygotowano teren pod obozy.

\footnotetext{
31 AP w Bydgoszczy, UWP w Toruniu, sygn. 9202a, Wychowanie rezerw i przysposobienie wojskowe, Obozy letnie PW - zarządzenie wykonawcze dowódcy OK nr VIII gen. bryg. Stefana Ludwika de Latour z 18 V 1923 r., k. 11; Obozy letnie - zasadniczy rozkaz organizacyjny dowódcy OK nr VIII gen. dyw. Jana Władysława Hubischty z 22 V 1924 r., k. 18; Obozy letnie - zasadniczy rozkaz organizacyjny dowódcy OK nr VIII gen. dyw. Jana Władysława Hubischty z 14 V 1925 r., k. 69; P. Saja, „Naród pod bronią”. Obozy letnie przysposobienia wojskowego dla młodzieży szkolnej i pozaszkolnej..., s. 30-35.
} 
Tabela 1. Dane dotyczące liczby zaplanowanych obozów i liczby miejsc dla uczestników szkolnych męskich obozów letnich PW ogólnego organizowanych przez DOK nr VIII (oprac. własne)

\begin{tabular}{|c|c|c|}
\hline Rok & Liczba obozów PW & Liczba miejsc \\
\hline 1928 & 4 & 500 \\
\hline 1929 & 6 & 700 \\
\hline 1930 & 7 & 700 \\
\hline 1932 & 8 & 880 \\
\hline 1935 & 10 & 1000 \\
\hline 1936 & 5 & 600 \\
\hline 1937 & 10 & 1000 \\
\hline 1938 & - & 1643 \\
\hline
\end{tabular}

Żródło: AP w Bydgoszczy, KOSP w Toruniu, sygn. 50, Wychowanie fizyczne i przysposobienie wojskowe 1922-1930, Okólnik MWRiOP z 10 V 1928 r. w sprawie obozów letnich dla młodzieży szkolnej i nauczycieli szkół powszechnych w 1928 r., zał. nr 1, k. 159; sygn. 57, Plan obozów i kursów letnich WF i PW MSWojsk. - 1929 r., „PUWFiPW MSWojsk. - plan obozów letnich PW w 1929 r., Warszawa 1929 r., zał. 4, k. 27; sygn. 51, Wychowanie fizyczne i przysposobienie wojskowe 1929-1930, Pismo MWRiOP do KOSP w Toruniu z 6 VI 1930 r. dotyczące obozów letnich PW hufców szkół średnich ogólnokształcących, seminariów nauczycielskich i szkół zawodowych, pkt. I, s. 1; Rozkaz OUWFiPW DOK nr VIII z 16 VI 1930 r. o organizacji obozów i kursów letnich PW w 1930 r., pkt. 1 i 4; sygn. 48, Wychowanie fizyczne i przysposobienie wojskowe 19321939, Plan OUWFiPW DOK nr VIII z 4 VI 1932 r. dotyczący obozów letnich PW w 1932 r., k. 301-303; Wychowanie fizyczne i przysposobienie wojskowe 1932-1939, Plan PUWFiPW MSWojsk. z 15 V 1938 r. dotyczący obozów letnich PW w 1938 r., zał. nr 1 (Plan obozów letnich PW ogólnego i specjalnego), k. 31; AP w Toruniu, AmT, sygn. 5960, Obozy letnie organizowane przez miasto Toruń oraz DOK nr VIII 19351936, Rozkaz OUWFiPW DOK nr VIII z 7 VI 1935 r. dotyczący organizacji obozów letnich PW w 1935 r., s. 1-2; sygn. 5934, Rozkazy i pisma OUWFiPW - 1937 r., Awizo OUWFiPW DOK nr VIII z 8 III 1937 r. o obozach letnich i kursach, k. 160; UWP w Toruniu, sygn. 9233, Sprawy WFiPW - 1936 r., Rozkaz OUWFiPW DOK nr VIII z 5 VI 1936 r. o organizacji obozów letnich PWiWF, k. 87.

Od początku lat trzydziestych obozy letnie PW dzielone były na turnusy. OUWFiPW DOK nr VIII, w zależności od zaplanowanej przez PUWFiPW MSWojsk. liczby obozów w danym roku, organizował zwykle 2 lub 3, a nawet 4 turnusy. I tak np. w 1931 r. były 2 turnusy ${ }^{32}$, w 1935 r. 4 turnusy $^{33}$, w 1936 r.

32 AP w Bydgoszczy, KOSP w Toruniu, sygn. 52, Wychowanie fizyczne i przysposobienie wojskowe 1931-1932, Zarządzenie OUWFiPW DOK nr VIII z czerwca 1931 r. dotyczące obozów letnich PW w Cetniewie i Lidzbarku Pomorskim, k. 421-423; Obozy letnie PW w Lidzbarku Pomorskim, „Młody Gryf” 1931, nr 17, s. 13; Obozy przysposobienia wojskowego DOK nr VIII w Cetniewie, „Młody Gryf” 1931, nr 19, s. 8-9.

33 AP w Toruniu, AmT, sygn. 5960, Obozy letnie organizowane przez miasto Toruń i DOK nr VIII 1935-1936, Rozkaz OUWFiPW DOK nr VIII z 7 VI 1935 r. dotyczący organizacji obozow letnich PW w 1935 r., s. 1-2; sygn. 5928, Okręgowy Urząd WF i PW - 1935 r., 
2 turnusy $^{34}$, w 1937 r. 3 turnusy ${ }^{35}$, w 19383 turnusy $^{36}$. Czyniono to dlatego, że w ramach poszczególnych turnusów oprócz obozów młodzieży szkolnej przygotowywane były także wspomniane wyżej obozy dla młodzieży pozaszkolnej i inne. Zdarzało się tak, że młodzież szkolna uczestniczyła tylko w jednym turnusie, zaś pozostałe były obsadzane przez uczestników innych obozów. Większa liczba turnusów zmuszała organizatorów do skrócenia czasu trwania każdego obozu. O ile np. w latach 1928-1930 obozy PW ogólnego dla młodzieży szkolnej męskiej planowano na 5 tygodni, to w latach następnych były one krótsze, np. w 1931 r. czas trwania obozu wynosił 2 tygodnie, w 1932 r. -3 tygodnie, w 1935 r. - 2 tygodnie, w 1936 r. - 18 dni, w 1937 r. - 18 dni, w 1938 r. - w zależności od turnusu 18 dni lub 3 tygodnie. Takie rozwiązanie dawało pewne oszczędności finansowe. Skrócenie czasu trwania obozów letnich PW ogólnego dla młodzieży szkolnej konieczne było również dlatego, że DOK nr VIII nie dysponowało wystarczającą liczbą ośrodków przeznaczonych na organizację obozów.

\section{Przygotowania i początek obozów}

Obozy letnie PW dla młodzieży organizowane były zgodnie z zaleceniami ustalanymi co roku przez PUWFiPW MSWojsk. Dane dotyczące liczby i rodzaju obozów oraz liczby uczestników podawane były w wydawanym w pierwszej połowie roku awizie i planie obozów przesyłanym do DOK. Na tej podstawie OUWFiPW opracowywały szczegółowy plan obozów i sporządzały rozdzielniki liczbowe z uwzględnieniem liczby miejsc dla uczestników różnych obozów PW przygotowywanych przez DOK, w tym obozów PW ogólnego dla młodzieży szkolnej męskiej. Potem, w formie pisemnej, informacje dotyczące obozów przesyłane były do obwodowych komend PW. Tam dokonywano podziału miejsc na poszczególne powiaty, biorąc pod uwagę przekazane wcześniej przez komendantów powiatowych PW dane dotyczące liczby kandydatów.

Listę imienną i liczbę junaków należących do hufców szkolnych PW, mających wziąć udział w obozach letnich, ustalały dyrekcje szkół razem

Awizo OUWFiPW DOK nr VIII z 5 IV 1935 r. o obozach letnich, zał. nr 2 (Plan obozów PW i kursów szkoły starszych w 1935 r.).

34 AP w Bydgoszczy, UWP w Toruniu, sygn. 9233, Sprawy WFiPW - 1936 r., Rozkaz OUWFiPW DOK nr VIII z 5 VI 1936 r. o organizacji obozów letnich PWiWF, k. 87.

35 AP w Toruniu, AmT, sygn. 5934, Rozkazy i pisma OUWFiPW - 1937 r., Awizo OUWFiPW DOK nr VIII z 8 III 1937 r. o obozach letnich i kursach, k. 160.

36 AP w Bydgoszczy, KOSP w Toruniu, sygn. 58, Obozy letnie przysposobienia wojskowego - 1938 r. Pismo MWRiOP z 10 VI 1938 r. w sprawie obozów letnich hufców szkolnych PW, k. 271-275; sygn. 48, Wychowanie fizyczne i przysposobienie wojskowe 1932-1939, Plan PUWFiPW MSWojsk. z 15 V 1938 r. dotyczący obozów letnich PW w 1938 r., zał. nr 1, (Plan obozów letnich PW ogólnego i specjalnego), k. 31. 
z komendantami powiatowymi PW. Uczniowie, aby pojechać, musieli spełnić następujące wymagania:

- mieć odpowiednie wyniki w nauce i nienagannie zachowywać się w szkole,

- wykazywać się dobrym stanem zdrowia, potwierdzonym zaświadczeniem wystawionym przez lekarza,

- posiadać świadectwo ukończenia I stopnia PW i przebyć rok szkolenia w II stopniu PW,

- dostarczyć zobowiązanie rodziców lub opiekunów, że w razie samowolnego opuszczenia lub karnego wydalenia $\mathrm{z}$ obozu pokryją koszty pobytu i przejazdu ${ }^{37}$.

$\mathrm{Na}$ obozy młodzież udawała się w grupach kilkudziesięcioosobowych pod nadzorem oficerów lub podoficerów z obwodu pułkowego PW, do którego należeli junacy. Po przyjeździe na miejsce opiekunowie przekazywali listy imienne z pozostałą dokumentacją (książeczki PWiWF, deklaracje junaków, zaświadczenia o stanie zdrowia, zgody rodziców lub opiekunów na udział w obozie) komendantowi grupy obozów. Uczestnicy przechodzili badania lekarskie i przydzielani byli do kompanii obozowych. Chorych i uznanych za niezdolnych do ćwiczeń polowych odsyłano do domu. Pozostali zakwaterowywani byli w namiotach 20-30-osobowych ${ }^{38}$. Każdy junak musiał przywieźć ze sobą koc, 2 prześcieradła, siennik, 2 koszule, 2 pary kalesonów, spodenki gimnastyczne, buty, kąpielówki, 3 pary skarpet, 2 ręczniki, przybory do mycia, przybory toaletowe, mydło, chustki do nosa, przybory do jedzenia ${ }^{39}$. Do drugiej połowy lat trzydziestych ci, którzy nie mieli mundurów, otrzymywali je na czas pobytu razem z oporządzeniem z zapasów wojskowych. Pod koniec lat trzydziestych nastąpiła zmiana. Komendanci obwodowi i powiatowi PW mieli dopilnować, aby junacy, jadąc na obóz letni, zabierali ze sobą mundur ćwiczebny, mundur wyjściowy, parę butów, pas,

37 AP w Bydgoszczy, KOSP w Toruniu, sygn. 51, Wychowanie fizyczne i przysposobienie wojskowe 1929-1930, Pismo MWRiOP do KOSP w Toruniu z 6 VI 1930 r. dotyczące obozów letnich PW hufców szkół średnich ogólnokształcących, seminariów nauczycielskich i szkół zawodowych, pkt. II, s. 1-2; sygn. 47, Program przysposobienia wojskowego dla hufców szkolnych - 1931 r., Zarządzenie Ministra Wyznań Religijnych i Oświecenia Publicznego i Ministra Spraw Wojskowych z 4 II 1931 r. w sprawie przysposobienia wojskowego w szkołach średnich ogólnokształcących, seminariach nauczycielskich i szkołach zawodowych, zał. $\mathrm{nr} 6, \mathrm{k}$. 51; sygn. 48, Wychowanie fizyczne i przysposobienie wojskowe 1932-1939, Instrukcja nr 12 PUWFiPW MSWojsk. o obozach letnich męskich, \$6, Warszawa 28 V 1932 r., k. 182.

38 P. Saja, „Naród pod broniq”. Obozy letnie przysposobienia wojskowego dla młodzieży męskiej w województwie pomorskim w latach 20-tych i 30-tych XX w., „Zeszyty Naukowe Toruńskiej Wyższej Szkoły Przedsiębiorczości” 2014, t. 1, s. 103.

39 AP w Bydgoszczy, Inspektorat Szkolny w Bydgoszczy, sygn. 262, Okólnik MWRiOP z $10 \mathrm{~V}$ 1928 r. w sprawie obozów letnich dla młodzieży szkolnej i nauczycieli szkół powszechnych, k. 168; AP w Bydgoszczy, KOSP w Toruniu, sygn. 52, Wychowanie fizyczne i przysposobienie wojskowe 1931-1932, Zarządzenie OUWFiPW DOK nr VIII z czerwca 1931 r. dotyczące obozow letnich PW w Cetniewie i Lidzbarku Pomorskim, k. 428-429. 
chlebak i 2 furażerki ${ }^{40}$. Komplety umundurowania miały być kupione przez samych uczestników lub dostarczone z zapasów komend obwodowych i powiatowych PW. Sprzęt łączności, broń, amunicję, mapy, regulaminy i pozostałe wyposażenie wojskowe i sportowe dostarczane było ze składów intendenckich DOK nr VIII, magazynów pułków piechoty i samodzielnych jednostek wyznaczonych $\mathrm{w}$ rozkazach organizacyjnych jako współodpowiedzialne za przygotowanie obozów. Obsadę personalną oficerów i podoficerów oraz personelu pomocniczego obozów letnich ustalał dowódca OK nr VIII, w porozumieniu z kierownikiem OUWFiPW DOK nr VIII oraz KOSP w Toruniu i Kuratorium Okręgu Szkolnego Poznańskiego.

\section{Struktura organizacyjna obozów letnich PW}

Podstawową jednostką obozów letnich PW młodzieży szkolnej PW ogólnego był pojedynczy obóz. Liczył od ok. 70 do 130 junaków. Mając na uwadze względy szkoleniowo-wojskowe, każdy obóz tworzył kompanię. Dzieliła się ona na plutony i drużyny. Zgodnie z instrukcją PUWFiPW MSWojsk. z 1932 r. w ramach jednego obozu-kompanii nie wolno było łączyć młodzieży szkolnej z pozaszkolnąa ${ }^{41}$, dlatego też osobno tworzone były obozy dla obu tych kategorii młodzieży. Zdarzało się jednak, jak np. w czasie obozów w 1935 r., że OUWFiPW wyrażał zgodę na to, aby dla uczestników, którzy z różnych powodów nie mogli przybyć na wyznaczony turnus, w późniejszym turnusie w ramach jednej kompanii tworzono plutony, z których jedne były dla młodzieży szkolnej, a drugie dla pozaszkolnej ${ }^{42}$.

Na obozach obowiązywała struktura organizacyjna taka sama jak w wojsku. Kompanią dowodził oficer mający pewne doświadczenie w pracy z młodzieżą na co dzień lub zdobyte na poprzednich obozach. Był odpowiedzialny za wychowanie, dyscyplinę, wyszkolenie i gospodarkę materiałową. Często funkcję tę pełnił komendant powiatowy jednej z komend PW działających przy pułkach piechoty stacjonujących w DOK nr VIII. Miał do pomocy, jako dowódców plutonów, 2-3 młodszych oficerów (podporuczników lub poruczników), podoficera zawodowego (sierżanta lub starszego

40 AP w Bydgoszczy, KOSP w Toruniu, sygn. 51, Wychowanie fizyczne i przysposobienie wojskowe 1929-1930, Pismo MWRiOP z 11 V 1929 r. dotyczące obozów letnich PW hufców szkolnych szkół średnich ogólnokształcących, seminariów nauczycielskich i szkół zawodowych, pkt II, s. 1-2; AP w Bydgoszczy, AP w Bydgoszczy, UWP w Toruniu, sygn. 9233, Sprawy WFiPW - 1936 r., Rozkaz OUWFiPW DOK nr VIII z 5 VI 1936 r. o organizacji obozów letnich PWiWF, k. 92.

${ }^{41}$ AP w Bydgoszczy, KOSP w Toruniu sygn. 48, Wychowanie fizyczne i przysposobienie wojskowe 1932-1939, Instrukcja nr 12 PUWFiPW MSWojsk. o obozach letnich męskich, $\S 3$, Warszawa 28 V 1932 r., k. 181.

42 AP w Toruniu, AmT, sygn. 5928, Okręgowy Urząd WFiPW - 1935, Zarządzenie OUWFiPW z 19 VII 1935 r. dotyczące obesłania [sic!] IV turnusu obozów letnich PW. 
sierżanta) jako szefa kompanii, a także 2 podoficerów zawodowych jako instruktorów. Instruktorami mogli być także odpowiednio przygotowani oficerowie kontraktowi czy oficerowie i podoficerowie rezerwy powołani na obóz w ramach obowiązkowych ćwiczeń. Na dowódców drużyn byli wybierani uczestnicy obozu lub junacy, którzy zgłosili się na ochotnika, a wcześniej brali udział w obozach letnich i mieli ukończony II stopień $\mathrm{PW}^{43}$.

Jednostką wyższego rzędu niż obóz była grupa obozów. W jej skład wchodziło od 2 do 5 kompanii. Dowodził nią komendant grupy obozów. Był nim zazwyczaj oficer w stopniu majora lub kapitana. Miał do dyspozycji niewielki sztab i personel pomocniczy składający się z oficerów, podoficerów i szeregowców funkcyjnych, w tym: zastępcę komendanta będącego jednocześnie oficerem wyszkolenia, oficera płatnika, oficera kwatermistrza, oficera lekarza (najpierw jeden na dwie grupy obozów PW, a potem dla każdej grupy jeden lekarz), oficera kierownika wychowania fizycznego, kapelana wojskowego (jeden na dwie grupy obozów), podoficera prowiantowego, podoficera kancelaryjnego, podoficera broni, podoficera mundurowego, podoficera kuchennego, patrol sanitarny (podoficer i 1-2 szeregowców), patrol telefoniczny (podoficer i 1-2 szeregowców), 4-5 kucharzy, trębacza, kilkunastu ordynansów, rymarza, krawca, szewca ${ }^{44}$. W składzie personelu był także 1 lub 2 cywilnych nauczycieli-pedagogów wydelegowanych przez KOSP lub Kuratorium Okręgu Szkolnego Poznańskiego. Każda grupa obozów uważana była za odrębną jednostkę administracyjno-szkoleniową. W jednym turnusie były przeważnie dwie grupy obozów. I tak np. na turnusie mogła być grupa obozów młodzieży szkolnej i grupa obozów młodzieży pozaszkolnej. Dla zachowania sprawności zarządzania dowództwo nad całością obejmował zawsze komendant pierwszej grupy obozów.

Obozy kontrolowane były przez władze kuratoryjne i wojskowe. Prawo do inspekcji obozów letnich PW ogólnego organizowanych przez DOK nr VIII mieli: dowódca OK lub kierownik OUWFiPW, wytypowany przez dowódcę OK wyższy oficer pełniący funkcję dowódcy piechoty dywizyjnej albo dowódcy pułku. Ponadto z kręgu najwyższych władz wojskowych obozy wizytować mógł także dyrektor PUWFiPW MSWojsk. oraz oficerowie Korpusu Kontrolerów ${ }^{45}$.

\footnotetext{
43 P. Saja, „Naród pod broniq̨”. Obozy letnie przysposobienia wojskowego dla młodzieży męskiej..., s. 104.

44 AP w Bydgoszczy, KOSP w Toruniu, sygn. 51, Wychowanie fizyczne i przysposobienie wojskowe 1929-1930, Rozkaz OUWFiPW DOK nr VIII z 16 VI 1930 r. dotyczący organizacji obozu letniego PW w Cetniewie, s. 2-3; sygn. 52, Wychowanie fizyczne i przysposobienie wojskowe 1931-1932, Zarządzenie OUWFiPW DOK nr VIII z czerwca 1931 r. dotyczące obozow letnich PW w Cetniewie i Lidzbarku Pomorskim, k. 422-425; AP w Bydgoszczy, UWP w Toruniu, sygn. 9233, Sprawy WFiPW - 1936 r., Rozkaz OUWFiPW DOK nr VIII z 5 VI 1936 r. o organizacji obozów letnich PWiWF, k. 88-89.

45 AP w Bydgoszczy, KOSP w Toruniu, sygn. 48, Wychowanie fizyczne i przysposobienie wojskowe 1932-1939, Instrukcja nr 12 PUWFiPW MSWojsk. o obozach letnich męskich, $\$ 11$, Warszawa 28 V 1932 r., k. 185.
} 
Z władz kuratorium prawo do kontroli miał kurator lub wyznaczony przez niego delegat ${ }^{46}$. Inspekcje mogły być przeprowadzane $\mathrm{w}$ czasie prac przygotowawczych przed przyjęciem uczestników, w trakcie turnusu albo podczas egzaminów końcowych. Kontrolujący zwracali uwagę na wykonanie zarządzeń zawartych w planie obozów co do wyszkolenia, zaopatrzenia, doboru kadry instruktorskiej i uczestników. Z wizytacji sporządzane były sprawozdania zawierające uwagi i wnioski.

\section{Porządek dnia, życie obozowe i szkolenie młodzieży}

Obozy letnie PW urządzane były na wzór wojskowy. Junacy byli uczeni samodzielności, dyscypliny, porządku, poczucia odpowiedzialności i zdolności życia w grupie. Aby przygotować młodzież do służby w wojsku, oprócz przestrzegania regulaminu obozowego, od $1925 \mathrm{r}$. wprowadzono obowiązek oddawania honorów przez junaków wszystkim oficerom i podoficerom z kadry obozowej. W każdą niedzielę kapelan wojskowy odprawiał mszę świętą, na którą przychodzili junacy i kadra wojskowa, z wyjątkiem dyżurnych i osób pełniących tego dnia służbę.

Wszyscy uczestnicy przestrzegać musieli ustalonego porządku dnia. Z drobnymi zmianami obowiązywał on w czasie całego okresu międzywojennego. W latach trzydziestych rozkład zajęć w powszednie dni przedstawia tabela 2.

Ważną rolę w czasie trwania obozów odgrywali nauczyciele-pedagodzy delegowani przez kuratoria okręgów szkolnych, w porozumieniu lub na wniosek OUWFiPW DOK. Jeden wychowawca przypadał na jedną grupę obozów. Byli nimi zazwyczaj nauczyciele zaangażowani w szkolenie PW i mający wykształcenie $z$ nauk przyrodniczych, historii, geografii lub wychowania fizycznego ${ }^{47}$. Sprawowali ogólny nadzór nad wychowaniem i zachowaniem junaków zwłaszcza w czasie wolnym od zajęć i szkolenia. Pod względem służbowym wychowawcy podlegali komendantowi grupy obozów, dyscyplinarnym zaś władzom kuratoryjnym. Działalność wychowawczą i edukacyjną realizowali według przygotowanego wcześniej planu zatwierdzonego przez kuratorium. Ich praca polegała na rozwiązywaniu problemów zaistniałych między kadrą dowódczą i instruktorską a młodzieżą, wygłaszaniu wykładów i pogadanek związanych $\mathrm{z}$ wiedzą o kraju, jego historii i tradycji, organizowaniu w wolnym czasie gawęd przy ognisku, a w dniach wolnych od zajęć wycieczek krajoznawczych np.

46 AP w Bydgoszczy, KOSP w Toruniu, sygn. 54, Wychowanie fizyczne i przysposobienie wojskowe 1937-1938, Zarządzenie Ministra Wyznań Religijnych i Oświecenia Publicznego oraz Ministra Spraw Wojskowych z 10 IX 1937 r. w sprawie organizacji przysposobienia młodzieży szkolnej do obrony kraju, zał. nr 1, pkt. III, $\$ 16$, k. 304.

47 AP w Bydgoszczy, KOSP w Toruniu, sygn. 57, Plan obozow i kursow letnich WFiPW MSWojsk. - 1929 r., PUWFiPW MSWojsk. - plan obozow letnich PW w 1929 r., Warszawa 1929 r., pkt. II, zał. nr 3, k. 25. 
do Gdyni czy na Półwysep Helski ${ }^{48}$. W stosunku do uczestników obozów letnich nauczyciele-pedagodzy nie mieli prawa karania, mogli jednak wystąpić z wnioskiem do komendanta grupy o ukaranie ucznia, a w przypadku ciężkich przewinień wysłać pismo do kuratorium o wyciągnięcie konsekwencji dyscyplinarnych lub wydalenie ze szkoły ${ }^{49}$. Swoją działalnością starali się zaszczepić w młodzieży uczucia patriotyczne i poczucie wspólnoty narodowej. Po zakończeniu obozów wychowawcy-pedagodzy opracowywali sprawozdanie z wykonanej pracy i przekazywali je komendantowi obozów. Potem trafiało ono również do władz kuratoryjnych. Uwzględniano w nim liczbę odbytych wycieczek, liczbę i tematy wygłaszanych pogadanek, zachowanie się uczniów na obozie, a także wnioski i spostrzeżenia ${ }^{50}$.

Tabela 2. Harmonogram zajęć dziennych obowiązujący w 1932 r. oraz w 1936 r. i 1938 r. (oprac. własne)

\begin{tabular}{|c|c|}
\hline Rok 1932 & Rok 1936 i 1938 \\
\hline $\begin{array}{l}\text { godz. } 5^{00}-\text { pobudka } \\
\text { godz. } 5^{00} \text { do } 5^{05} \text { - modlitwa } \\
\text { godz. } 5^{05} \text { do } 6^{00}-\text { gimnastyka, porządki } \\
\text { godz. } 6^{00} \text { do } 7^{00}-\text { mycie się, ubieranie } \\
\text { i śniadanie } \\
\text { godz. } 7^{00} \text { do } 11^{00} \text { - ćwiczenia } \\
\text { godz. } 11^{30}-\text { raport } \\
\text { godz. } 11^{30} \text { do } 14^{00} \text { - obiad i czas wolny } \\
\text { godz. } 14^{00} \text { do } 15^{30} \text { - kąpiel i plaża } \\
\text { godz. } 15^{30} \text { do } 18^{00} \text { - ćwiczenia sportowe } \\
\text { i gry oraz wykłady z PW } \\
\text { godz. } 18^{00} \text { do } 18^{30}-\text { apele i przeglądy } \\
\text { godz. } 18^{30} \text { do } 18^{35} \text { - odczytanie rozkazu } \\
\text { na dzień następny } \\
\text { godz. } 18^{35} \text { do } 19^{30}-\text { kolacja } \\
\text { godz. } 19^{30} \text { do } 20^{30} \text { - czas wolny } \\
\text { godz. } 20^{30} \text { do } 20^{45} \text { - apel wieczorny, modlitwa } \\
\text { godz. } 20^{45} \text { do } 21^{00} \text { - przygotowanie do snu } \\
\text { godz. } 21^{00}-\text { capstrzyk. }\end{array}$ & $\begin{array}{l}\text { godz. } 6^{00}-\text { pobudka } \\
\text { godz. } 6^{00} \text { do } 6^{30}-\text { modlitwa i gimnastyka } \\
\text { godz. } 6^{30} \text { do } 7^{50}-\text { mycie się, ubieranie, } \\
\text { porządki i śniadanie } \\
\text { godz. } 7^{50} \text { do } 8^{00}-\text { zbiórka, podniesienie } \\
\text { flagi i wymarsz na ćwiczenia } \\
\text { godz. } 8^{00} \text { do } 11^{30}-\text { zajęcia wg programu } \\
\text { godz. } 11^{30} \text { do } 12^{00}-\text { raport, przetarcie broni } \\
\text { godz. } 12^{00} \text { do } 14^{30} \text { - obiad i wypoczynek } \\
\text { poobiedni } \\
\text { godz. } 14^{30} \text { do } 17^{30}-\text { zajęcia popołudniowe } \\
\text { godz. } 17^{30} \text { do } 18^{30}-\text { czyszczenie broni, } \\
\text { porządki w namiotach, odczytanie rozkazu } \\
\text { godz. } 18^{30} \text { do } 19^{30}-\text { kolacja } \\
\text { godz. } 19^{30} \text { do } 20^{30}-\text { czas wolny lub ognisko } \\
\text { godz. } 20^{30} \text { do } 20^{45} \text { - apel wieczorny, } \\
\text { modlitwa, opuszczenie flagi } \\
\text { godz. } 20^{45} \text { do } 21^{00}-\text { przygotowanie do snu } \\
\text { godz. } 21^{00}-\text { capstrzyk. }\end{array}$ \\
\hline
\end{tabular}

Źródło: AP w Bydgoszczy, KOSP w Toruniu, sygn. 48, Wychowanie fizyczne i przysposobienie wojskowe 1932-1939. Plan obozów letnich OUWFiPW DOK nr VIII z 4 VI 1932 r. Rozkład dnia w obozach młodzieży szkolnej, k. 317; UWP w Toruniu, sygn. 9205, Wojewódzki Komitet WFiPW w Toruniu. Plan obozów letnich PW ogólnego na 1936 rok, zał. nr 3 (Rozkład dnia na obozach letnich PW ogólnego), s. 1;

48 Obozy przysposobienia wojskowego DOK nr VIII..., s. 9; Na straży zdrowia $i$ sportu. W obozie junaków z cenzusem, „Straż nad Wisłą” 1936, nr 8, s. 10-11.

49 AP w Bydgoszczy, KOSP w Toruniu, sygn. 57, Plan obozów i kursów letnich WFiPW MSWojsk. - 1929 r., PUWFiPW MSWojsk. - plan obozów letnich PW w 1929 r., Warszawa 1929 r., pkt. VII, k. 25.

50 Ibidem, pkt. VI, k. 25. 
KOSP w Toruniu, sygn. 48, Wychowanie fizyczne i przysposobienie wojskowe 19321939. Plan PUWFiPW MSWojsk. z 15 V 1938 r. dotyczący obozow letnich PW w 1938 r., zał. nr 5 (Rozkład dnia na obozach letnich PW ogólnego), k. 35; P. Saja, „Naród pod bronią". Obozy letnie przysposobienia wojskowego dla młodzieży szkolnej i pozaszkolnej..., s. 105-106.

W czasie obozów letnich PW zdarzały się przypadki łamania regulaminu obozowego przez uczestników. Najczęściej były to drobne wykroczenia, takie jak: spóźnianie się na zbiórki, niewykonywanie w wyznaczonym czasie poleceń przełożonych, złe pełnienie służby, brak dbałości o porządek w namiotach. Kary, jakie otrzymywali junacy od swoich przełożonych, miały charakter dyscyplinujący. Winni zazwyczaj otrzymywali naganę, wykonywali dodatkowe prace porządkowe na terenie obozu lub pełnili służbę poza kolejnością. Lżejsze przypadki łamania dyscypliny rozstrzygać mogły sądy koleżeńskie. Niektórzy junacy, choć takie przypadki należały do rzadkości, dopuszczali się również poważniejszych przewinień, np. kradzieży czy bicia kolegów. Za te czyny mogli być wydaleni z obozów. Wówczas musieli pokryć koszty dotychczasowego pobytu i podróży. W drastycznych przypadkach łamania dyscypliny, jak np. nieprzybycie lub ucieczka $z$ obozu, komendanci grupy obozów dodatkowo wnioskowali do władz KOSP w Toruniu o wyciągnięcie poważniejszych konsekwencji, do usunięcia ze szkoły włącznie ${ }^{51}$.

Ogólny program nauki i szkolenia z PW podawany był w wytycznych PUWFiPW MSWojsk. Był on zmieniany i dostosowywany do bieżących potrzeb szkoleniowych. Kładziono w nim nacisk przede wszystkim na ćwiczenia praktyczne. Na jego podstawie dowódcy obozów opracowywali szczegółowy program szkolenia. W czasie pobytu na obozie letnim młodzież pogłębiała wiedzę m.in. z zakresu terenoznawstwa, obsługi i użycia broni, walki na bagnety, rzutu granatem, służby łączności i wyszkolenia saperskiego, musztry, regulaminów. Jako przykład posłużyć mogą wykazy godzin przewidziane na realizację opracowanych programów z poszczególnych przedmiotów, podane $\mathrm{w}$ tabeli 3 . Zajęcia te przeprowadzane były w czasie trzytygodniowych obozów letnich PW ogólnego w Cetniewie i Lidzbarku Pomorskim w 1932 r. Choć liczba godzin w wymiarze ogólnym była ta sama, na poszczególne przedmioty przeznaczano różną liczbę godzin. Zależało to od rodzaju szkół, z których pochodziła młodzież. Istniały pewne różnice, w zależności od tego, czy programy przeznaczone były dla junaków szkół średnich z cenzusem, czy dla junaków szkół niższych bez cenzusu.

51 P. Saja, „Naród pod bronią". Obozy letnie przysposobienia wojskowego dla młodzieży męskiej..., s. 111. 
Tabela 3. Nazwy przedmiotów i liczba godzin przeznaczona w programie szkolenia PW ogólnego dla młodzieży szkolnej w czasie obozów letnich w 1932 r.

\begin{tabular}{|l|c|l|c|}
\hline $\begin{array}{c}\text { Obozy dla młodzieży ze szkół średnich } \\
\text { ogólnokształcących, seminariów } \\
\text { nauczycielskich i średnich szkół } \\
\text { zawodowych (z cenzusem) w Cetniewie }\end{array}$ & $\begin{array}{r}\text { Obozy dla młodzieży ze szkół } \\
\text { niższych zawodowych handlowych, } \\
\text { przemysłowych itp. (bez cenzusu) } \\
\text { w Lidzbarku Pomorskim }\end{array}$ \\
\hline \multicolumn{1}{|c|}{ Nazwa przedmiotu } & Liczba godzin & Nazwa przedmiotu & Liczba godzin \\
\hline Wychowanie fizyczne & 44 & Wychowanie fizyczne & 48 \\
\hline Wyszkolenie strzeleckie & 18 & Wyszkolenie strzeleckie & 26 \\
\hline Terenoznawstwo & 22 & Terenoznawstwo & 28 \\
\hline Wyszkolenie saperskie & 18 & - & - \\
\hline Nauka służby & 4 & Nauka służby & 4 \\
\hline Razem & 22 & Razem & 22 \\
\hline
\end{tabular}

Źródło: AP w Bydgoszczy, KOSP w Toruniu, sygn. 48, Wychowanie fizyczne i przysposobienie wojskowe 1932-1939, Plan OUWFiPW DOK nr VIII z 4 VI 1932 r. dotyczący obozow letnich PW w 1932 r., k. 301-317.

Po zrealizowaniu całości programu szkolenia z II stopnia PW, jeszcze przed zakończeniem turnusu, odbywały się egzaminy, które junacy zdawali przed specjalnie powołaną w tym celu komisją. $W$ jej skład wchodzili: jako przewodniczący - oficer sztabowy wyznaczony przez dowódcę OK nr VIII, a jako członkowie - dowódca grupy obozów, dowódca kompanii obozowej, młodszy oficer lub instruktor. Egzamin polegał na przeprowadzeniu ogólnego przeglądu poziomu wyszkolenia zdających $\mathrm{z}$ obowiązujących $\mathrm{w}$ danym okresie programów i wytycznych na II stopień PW ustalonych przez PUWFiPW MSWojsk. ${ }^{52}$ Sprawdzano także, czy kandydat ukończył I stopień PW oraz informacje zapisane w książeczkach WFiPW o toku szkolenia na II stopień PW, takie jak: odbyte ćwiczenia i strzelania z broni małokalibrowej i wojskowej, zaliczone próby o Państwową Odznakę Sportową (POS), obecność przynajmniej na 85\% marszów i zbiórek. Skala ocen była następująca: bardzo dobra - 4, dobra - 3, dostateczna - 2, niedostateczna - 1. Świadectwo II stopnia PW mógł dostać uczestnik obozów, który z wszystkich przerabianych działów wyszkolenia otrzymał przynajmniej notę dostateczną ${ }^{53}$. Na zakończenie obozu uczestnicy, którzy osiągnęli najlepsze wyniki, otrzymywali nagrody ${ }^{54}$. Tak było np. na

52 AP w Bydgoszczy, KOSP w Toruniu, sygn. 53, Wychowanie fizyczne i przysposobienie wojskowe 1930-1932, Instrukcja nr 17 PUWFiPW MSWojsk. o przeprowadzaniu egzaminów i wydawaniu zaświadczeń pracy w PW, cz. II, \$ 5, pkt a i b, Warszawa 1932.

53 Ibidem, cz. II, $₫ 6$.

${ }^{54}$ Obozy przysposobienia wojskowego DOK nr VIII..., s. 9. 
koniec II turnusu obozów PW zorganizowanych w Lidzbarku Pomorskim dla młodzieży szkół niższych zawodowych, a także dla młodzieży pozaszkolnej. Przed południem 30 lipca 1931 r., który był ostatnim dniem obozów, uczestnicy zdali otrzymany wcześniej sprzęt i wyposażenie. O godz. $12^{00}$ zjedli obiad, po którym nastąpiło rozdanie nagród. Za bardzo dobre wyniki ze szkolenia PW nagrodę otrzymały 3 osoby, za osiągnięcia $z$ wychowania fizycznego 3 osoby, za bardzo dobre wyniki w strzelaniu z broni małokalibrowej 3 osoby, z broni wojskowej 3 osoby ${ }^{55}$. Ponadto 40 junaków zaliczyło próby na POS. Potem, pod opieką kadry wojskowej, uczestnicy obozów grupami odjechali do domu.

Z przeprowadzanych egzaminów końcowych spisywany był protokół. Ponadto komisja sporządzała także imienny wykaz zdających z ocenami z poszczególnych działów szkolenia $\mathrm{PW}$ i otrzymaną notą końcową. Komendant grupy obozów, po zakończeniu turnusu, przesyłał oryginał protokołu z imienną listą i świadectwami ukończenia II stopnia PW komendantom obwodów PW, z którego pochodzili zdający uczestnicy. Z kolei komendanci obwodowi wprowadzali dane do ewidencji personalnej członków PW i przekazywali świadectwa ukończenia II stopnia PW komendantom powiatowym PW. Potem świadectwa przekazywane były junakom.

W czasie przygotowywania i trwania obozów letnich PW powstawały pewne niedomagania i trudności organizacyjno-szkoleniowe. Zdarzało się, że na początku obozów letnich PW zabrakło odpowiedniej ilości sprzętu i zaopatrzenia niezbędnego w szkoleniu wojskowym. Dotyczyło to również jakości i ilości wyżywienia. Zdobyte w czasie obozów letnich doświadczenie organizacyjne pozwalało OUWFiPW DOK nr VIII na usunięcie niedociągnięć. Staranniej dobierano kadrę oficerską, podoficerską i instruktorską. Lepiej przygotowane było zaplecze kwatermistrzowskie oraz organizacja szkolenia i wychowania młodzieży. Dla poparcia tego stwierdzenia przytoczyć warto fragment rozkazu komendanta obozów letnich w Cetniewie mjr. Jana Zgórnickiego z 18 sierpnia 1930 r. Czytamy w nim m.in: „Wyniki końcowych egzaminów z wyszkolenia PW, w ogólności z bojowego i strzeleckiego wykazały, że oficerowie i podoficerowie czas pobytu uczniów w obozach wykorzystali z całą sumiennością i wielkim zrozumieniem idei PW. Duża znajomość właściwości psychicznych młodzieży, utrzymanie jej w karności posłuszeństwie przez cały czas pobytu w obozach, umiejętności postępowania z młodzieżą oraz takt charakteryzowały wszystkich oficerów. Podkreślić muszę, że ścisła i zgodna współpraca nauczycieli-wychowawców z korpusem oficerskim oraz gorliwa ich praca nad wychowaniem uczniów, przyczyniły się w dużej mierze, że końcowe wyniki wykazały pod każdym względem bardzo dobre rezultaty, co również

55 Zakończenie obozu WF i PW w Lidzbarku, „Młody Gryf” 1931, nr 21, s. 15. 
stwierdziła komisja PUWFiPW w czasie swojej inspekcji, uważając obozy PW w Cetniewie za wzorowe" 56 .

\section{Zakończenie}

Reasumując, podkreślić należy, że na obozach letnich młodzież w warunkach polowych utrwalała wiedzę teoretyczną zdobytą wcześniej w czasie zajęć w hufcach szkolnych PW oraz nabywała nowe umiejętności. Młodzi ludzie oprócz wiedzy i doświadczenia wojskowego rozwijali także sprawność ruchową przez udział w zaprawach porannych, ćwiczeniach polowych, zawodach, grach i zabawach sportowych. Rozwój tężyzny fizycznej miał wpływ na stan zdrowia młodego pokolenia, które z powodu zaborów, I wojny światowej 1914-1918 i wojny polsko-bolszewickiej 1919-1921 dopiero w niepodległej Polsce objęte zostało opieką państwa umożliwiającą popularyzację rozwoju fizycznego i nadrobienie zaległości edukacyjnych.

Edukacja z zakresu PW w szkole oraz pobyt na obozach letnich pozwalał zdobyć młodzieży także inne doświadczenia. Junacy uczyli się żyć w grupie $\mathrm{w}$ określonym przez regulamin rygorze. Wyrabiali w sobie poczucie tolerancji i solidarności grupowej. W czasie wycieczek krajoznawczych poznawali polskie Wybrzeże i okoliczną przyrodę. Wysłuchując prelekcji i biorąc udział w pogadankach przeprowadzanych przez nauczycieli-wychowawców, pogłębiali wiedzę o historii Polski, o jej ustroju politycznym i gospodarczym, kulturze i tradycji. Edukacja wychowawcza, co należy zaakcentować w sposób szczególny, ukierunkowana była na wychowanie obywatela-patrioty. Miało to bardzo duże znaczenie w całokształcie procesu wychowawczego młodego pokolenia.

Skutki tej edukacji były zauważalne w bliskiej przyszłości. Niektórzy związali swoją karierę zawodową ze służbą w wojsku lub pracą w instytucjach zapewniających bezpieczeństwo państwa. W czasie kampanii polskiej w 1939 r. młodzież, która przeszła szkolenie w hufcach szkolnych i na obozach letnich, pełniła $\mathrm{w}$ jednostkach PW pomocniczą służbę, odciążając oddziały regularnego wojska. Junacy także pomagali żołnierzom w walce z nieprzyjacielem, jak to było np. w Bydgoszczy 3 i 4 września 1939 r. podczas tzw. „krwawej niedzieli”, przygotowanej przez niemiecką V kolumnę, czy też w Inowrocławiu - gdzie m.in. junacy z PW 8 września 1939 r. stawiali zbrojny opór wkraczającym do miasta regularnym pododdziałom 337 Pułku Piechoty z niemieckiej 208 DP. Absolwenci szkoleń PW w czasie okupacji działali w strukturach konspiracyjnych ruchu oporu. Wśród nich

56 AP w Bydgoszczy, KOSP w Toruniu, sygn. 51, Wychowanie fizyczne i przysposobienie wojskowe 1929-1930, Rozkaz dzienny nr 40 Komendanta Całości Obozów Letnich PW DOK nr VIII w Cetniewie mjr. Jana Zgórnickiego, 18 VIII 1930 r., s. 1. 
byli też i tacy, którzy po zakończeniu II wojny światowej nadal prowadzili walkę $\mathrm{w}$ organizacjach podziemia niepodległościowego z narzuconym Polsce ustrojem komunistycznym i dominacją sowiecką.

\section{Bibliografia}

\section{Archiwalia}

Archiwum Państwowe w Bydgoszczy

Inspektorat Szkolny w Bydgoszczy

Kuratorium Okręgu Szkolnego Pomorskiego

Urząa Wojewódzki Pomorski

Archiwum Państwowe w Toruniu

Akta miasta Torunia

\section{Akty prawne}

Rozporządzenie Ministra Wyznań Religijnych i Oświecenia Publicznego i Ministra Spraw Wojskowych z 1 XII 1922 r. w sprawie organizacji przysposobienia wojskowego w szkołach średnich i zawodowych (Dz. U. M. W. R. i O. P. 1923, nr 1, poz. 2).

Rozporządzenie Ministra Wyznań Religijnych i Oświecenia Publicznego z 5 I 1923 r. w sprawie przysposobienia wojskowego młodzieży szkolnej (Dz. U. M. W. R. i O. P. 1923, nr 1, poz. 3).

Rozporząadzenie Rady Ministrów z 28 I 1927 r. w sprawie utworzenia Państwowego Urzędu Wychowania Fizycznego i Przysposobienia Wojskowego oraz wojewódzkich, powiatowych i miejskich komitetów wychowania fizycznego i przysposobienia wojskowego (M. P. 1927, nr 26, poz. 59).

\section{Publikacje}

Fularski M., Przysposobienie wojskowe w Polsce, Warszawa 1929.

Kęsik J., Naród pod bronią. Społeczeństwo w programie polskiej polityki wojskowej, 1918-1939, Wrocław 1998.

Obozy przysposobienia wojskowego DOK nr VIII w Cetniewie, „Młody Gryf” 1931, nr 19.

Rada Naukowa Wychowania Fizycznego, „Wychowanie Fizyczne” 1927, z. 4, s. 100-101.

Rada Naukowa Wychowania Fizycznego (dokończenie), „Wychowanie Fizyczne” 1927, z. 6, s. 156-158.

Rozwadowski P., Państwowy Urząd Wychowania Fizycznego i Przysposobienia Wojskowego, Warszawa 2000.

Saja P., Komitety Wychowania Fizycznego i Przysposobienia Wojskowego w województwie pomorskim w okresie Drugiej Rzeczypospolitej, Toruń 2012.

Saja P., „Naród pod broniq”. Obozy letnie przysposobienia wojskowego dla młodzieży szkolnej i pozaszkolnej na Pomorzu w latach 1922-1925, „Przegląd Historyczno-Wojskowy" 2009, nr 4 (229), s. 25-40.

Saja P., „Naród pod bronią". Obozy letnie przysposobienia wojskowego dla młodzieży męskiej w województwie pomorskim w latach 20-tych i 30-tych XX w., „Zeszyty Naukowe Toruńskiej Wyższej Szkoły Przedsiębiorczości” 2014, t. 1. 
Saja P., Organizacja władz przysposobienia wojskowego na obszarze DOK nr VIII na przełomie lat dwudziestych i trzydziestych XX wieku [w:] Materialy z III międzynarodowej konferencji naukowej p.h. Od armii komputowej do narodowej. Problemy organizacyjne sit zbrojnych od XVI do XX wieku, red. J. Centek i M. Krotofil, Toruń 2009, s. 303-314.

Wojtycza J., Przysposobienie wojskowe w odrodzonej Polsce do 1926 roku, Kraków 2001. Wyszczelski L., Ministerstwo Spraw Wojskowych (1918-1939), Warszawa 2010. Zakończenie obozu WF i PW w Lidzbarku, „Młody Gryf” 1931, nr 21, s. 15.

\section{STRESZCZENIE}

Piotr Saja, Przygotowanie wojskowe młodzieży szkolnej i obozy letnie przysposobienia wojskowego ogólnego męskiego na Pomorzu pod koniec lat dwudziestych i w latach trzydziestych $\mathrm{XX}$ wieku

Autor w pierwszej części artykułu, mającej wprowadzić czytelnika w tematykę, dokonał krótkiej charakterystyki zmian mających na celu upowszechnienie szkolenia z przysposobienia wojskowego (PW) w placówkach oświatowych w drugiej połowie lat dwudziestych i w latach trzydziestych XX w. W ogólnym zarysie przedstawił instytucje odpowiedzialne za edukację obronną młodego pokolenia. Dokonał charakterystyki celów i zadań w przygotowaniu młodzieży z tej dziedziny w hufcach szkolnych. Omówił również strukturę organizacyjną hufców PW oraz w zwięzłej formie przedstawił program nauczania na poszczególne stopnie PW.

Jednak zasadnicza treść publikacji dotyczy obozów letnich PW ogólnego. W krótkich podrozdziałach, na podstawie głównie źródeł archiwalnych, autor starał się ukazać problematykę związaną z organizacją i przebiegiem obozów letnich PW na Pomorzu. W artykule opisał sposób rekrutacji i wymagania stawiane uczestnikom obozów. Przedstawił strukturę organizacyjną obozów letnich PW, szkolenie wojskowe w czasie ich trwania, obowiązujący porządek dnia i wymagania dyscyplinarne. Opisał też rolę cywilnych wychowawców-pedagogów w procesie edukacji patriotycznej młodzieży, a także egzaminy końcowe na II stopień PW.

Słowa kluczowe: DOK, PW, OUWFiPW, PUWFiPW, KOSP, hufiec szkolny PW, junak, obozy letnie, grupa obozów, turnus

\section{SUMMARY}

\section{Piotr Saja, Civil defense training of school youth and men's general civil defense summer camps in Pomerania at the end of the 1920s and in the 1930s}

In the first part of the article, the purpose of which is to introduce the subject matter to the reader, the author has made a brief description of the changes aimed at popularizing civil defense training in educational institutions in the second half 
of the 1920s and 1930s. A general outline of the institutions responsible for the defense training of the young generation has been presented, and a characteristics of the objectives and tasks in the preparation of young people in this field in school scout troops has been made. The author has also discussed the organizational structure of the school scout troops of civil defense, and briefly presented the curriculum for the different civil defense ranks.

However, the core of the publication concerns general civil defense summer camps. In short subsections, basing mainly on archival sources, the author has attempted to present the issues related to the organization and course of these camps in Pomerania. Recruitment methods and requirements for camp participants have been described in the article. The author has presented the organizational structure of the civil defense summer camps, the military training they covered, the daily agenda and disciplinary requirements. He also described the role of civilian counsellors and educators in the process of patriotic education of young people, as well as the final exams for the $2^{\text {nd }}$ rank in civil defense.

Keywords: DOK, civil defense training, OUWFiPW, PUWFiPW, KOSP, school scout troop of civil defense, junak, summer camps, camp group, turnus

\section{PEЗЮME}

\section{Петр Сая, Военная подготовка (ВП) школьной молодежи и летние лагеря ВП общего типа для юношей в Померании в конце 20-х гг. и в 30-х гг. XX века}

В первой части статьи, цель которой - ознакомить читателя с темой, автор представил краткую характеристику изменений, которые должны были привести к распространению военной подготовки в образовательных учреждениях во второй половине 20-х гг. и в 30-х гг. XX в. Также в статье в общих чертах представлены учреждения, отвечающие за образование молодого поколения в сфере обороны, составлена характеристика целей и заданий, используемых при подготовке молодежи по соответствующим дисциплинам в школьных отрядах. Кроме того, описана организационная структура отрядов ВП, а также кратко представлена программа обучения с разделением на отдельные уровни ВП.

Однако основное содержание публикации касается собственно летних лагерей ВП общего типа. В коротких подразделах, материал которых базируется преимущественно на архивных источниках, автор попытался описать проблемы, связанные с организацией и устройством летних лагерей ВП в Померании.

Также в статье были описаны условия приема и требования к участникам лагеря, представлена организационная структура летних лагерей, описаны занятия по военной подготовке, расписание дня и дисциплинарные требования. Кроме того, автор описывает роль гражданских педагогов-воспитателей в процессе патриотического воспитания молодежи, а также выпускные экзамены на 2-ю степень ВП. 
Ключевые слова: Окружное Командование корпусами, военная подготовка, Государственное и Районное Управление физической культуры и военной подготовки, Управление школьного образования Поморского округа, школьный отряд ВП, юнак, летние лагеря, группа лагерей, лагерь 